\title{
APPLICATION OF RANDOM REGRESSION MODELS FOR GROWTH TRAITS OF NELLORE CATTLE IN BRAZIL
}

\author{
FONSECA, Wéverton José Lima ${ }^{1}$ \\ EVANGELISTA, Amauri Felipe ${ }^{1}$ \\ BORGES, Laylson da Silva ${ }^{1}$ \\ VOGADO, Gleissa Mayone Silva ${ }^{2}$ \\ CAVALCANTE, Diego Helcias ${ }^{1}$ \\ OLIVEIRA, Marcelo Richelly Alves de ${ }^{1}$ \\ CAMPELO, José Elivalto Guimarães ${ }^{3}$ \\ CARVALHO, Marcos David Figueiredo de ${ }^{3}$
}

SUMMARY: Thepurpose of thisreview isto show the increase in number of researches on covariance components and genetic evaluation using random regression models (RRM) for growth traits of Nellore cattle. Random regression models (RRM), also known as infinite-dimension models have been used to estimate variance components and genetic parameters for weight of beef cattle. In addition, those models are a standard alternative for genetic analyses of longitudinal data, however, the availibility of computational resources for performing genetic evaluations widely is an obstacle. Traits related to animal growth are adopted as selection criteria in beef cattle breeding programs, because the remuneration of cattle breeders is made based on the weight of carcasses. In recent years, RRM have been adopted as standard procedure in relation to the analysis of longitudinal data in animal breeding.

Keywords: Genetic evaluation. Longitudinal data. Nellore cattle.

\section{APLICAÇÃO DE MODELOS DE REGRESSÃO ALEATÓRIA PARA CARACTERÍSTICAS DE CRESCIMENTO DA RAÇA NELORE NO BRASIL}

\begin{abstract}
RESUMO: Objetivou-se com esta revisão de literatura compilar informações sob a avaliação genética utilizando modelos de regressão aleatória (MRA) para características de crescimento em bovinos da raça Nelore. Os modelos de regressão aleatória (MRA), denominados modelos de dimensão infinita, estão sendo utilizados para estimar os componentes de variância e parâmetros genéticos de pesos de bovinos de corte. Os MRA têm se tornado uma alternativa padrão para análises genéticas de dados longitudinais, onde um dos entraves destes modelos está relacionado à disponibilidade de memória e tempo computacional para a realização de avaliações genéticas em larga escala. Características relacionadas ao crescimento animal são adotadas em programas de melhoramento genético de bovinos de corte como critérios de seleção, pelo fato da remuneração, dos produtores, ser feita com base no peso das carcaças. Nos últimos anos, os MRA têm sido adotados como procedimento padrão para análise de dados longitudinais em melhoramento genético animal.
\end{abstract}

Palavras-chave: Avaliação genética. Dados longitudinais. Nelore.

\footnotetext{
${ }^{1}$ Programa de Pós-Graduação em Ciência Animal, Universidade Federal do Piauí - (UFPI), Teresina, Brasil. E-mail: fonsecaufpi@gmail.com.*Autor para correspondência.

${ }^{2}$ Graduanda Zootecnia, Universidade Federal do Piauí - (UFPI), Bom Jesus, Brasil. ${ }^{3}$ Departamento de Zootecnia, Centro de Ciencias Agrárias ${ }^{-(\mathrm{CCA} / \mathrm{UPPI}),}$ Teresina ${ }^{\text {Brazil. }}$
} 


\section{INTRODUCTION}

The study of early stages of beef cattle growth has great importance to obtain an efficient growth by increasing the precocity of animals. Generally, this study is carried out by non-linear functions that generate parameters with biological interpretation, when are fitted to data of weight and age. Knowledge of these parameters associated with reproductive traits of animals may be an alternative for selection programs aimed at increasing the precocity of the herd (SILVA et al., 2002).

In Brazil, genetic evaluation studies of the growth curve of beef cattle as body weight and measures in the early stages of animal development are important characteristics in determining the economic efficiency and are used in the genetic evaluation of breeding programs. The genetic evaluation of beef cattle depends mainly on the availability of estimates of genetic parameters for the traits of economic interest (SOUSA JÚNIOR et al., 2010a).

Random regression models (RRM), called infinite-dimensional models have been used to estimate the variance components and genetic parameters of beef cattle weights. These models have become an alternative standard for genetic analyses of longitudinal data, where the availability of memory and computational time to perform genetic evaluations on a large scale represents an obstacle for the use of these models (SOUSA JÚNIOR et al., 2014).

Conventional analyses to estimate (co)variance components and genetic parameters for growth traits are performed by finite-dimensional models. For estimating the (co)variance components to obtain the genetic parameters and breeding values, the choice of the most appropriate methods to be used in the estimation of (co)variance components and genetic parameters is essential in genetic evaluations (GIANOLA;FERNANDO, 1986).

It is of great importance for the development in livestock, the study of covariance components and genetic evaluation using random regression models for growth traits in Nellore cattle, as they allow greater genetic advances and production gains. Thus, the purpose of this literature review was to compile information on genetic evaluation using random regression models (MRA) for growth traits in Nellore cattle.

\section{IMPORTANCEOFBEEF CATTLE FARMING}

The beef cattle production system has important role in the economic development of Brazil, contributing 28.9\% to the Brazilian agribusiness GDP (Gross Domestic Product). According to Brazil Ministry of Agriculture, Livestock and Food Supply (MAPA, 2009), the Brazilian beef production is undergoing a modernization process motivated by the need to increase its efficiency, as the introduction and demand for other meats, and requirement to 
produce with environmental sustainability have increased competitiveness, increasing market competition (AMARAL, 2014).

According to the Association of Brazilian Beef Exporters (ABIEC, 2013), in 2013, Brazil had the largest commercial herd of cattle in the world, with about 208 million animals and produced approximately 10.2 million equivalent tons of carcass, with $81.4 \%$ of this production for the domestic market and $19.6 \%$ for the foreign market. Within the agricultural GDP, livestock accounts for about $43 \%$, which demonstrates its economic and social importance for the country (MARTINEZ et al., 2004).

The importance of a breed for region largely depends on animal's genetic and in this regard, estimates of population parameters provide important information about the genetic nature of the traits of economic importance and are necessary to predict the direct and correlated answers when subjected to selection, and formulating indexes for selecting the most suitable selection methods (BIFFANI et al., 1999).

In studies which can be performed to increase herd cattles's production, identifying the best individuals for breeding deserves in-depth researches with respect to nutrition, health, ambience, management, and the determination of genetic evaluation parameters that contribute to improve the productivity of beef cattle farming (OLIVEIRA, 2015).

\section{GROWTHMODELLING}

The modelling, considering the heterogeneous residual variances for each class, may enhance the partition of the total variation, but increases the number of parameters to be estimated (AMBROSINI, 2012). The high number of parameters in model, the covariance structure and the higher density of incidence matrices when compared to conventional models, may difficult the convergence in the estimation of variance components, which represent obstacles to the use of the reaction norms methodology for genetic evaluations in sets with large amounts of data (CORRÊA, 2007).

The genetic evaluation of beef cattle growth curve depends on estimates of genetic parameters for the traits of economic interest. For these parameters are reliable, the genetic evaluation methodologies must be correctly applied for the predicted values can be accurate, and thus actually represent an effective tool at selecting in search of genetic progress of the herd (FARIA et al., 2007). Breeding values for traits of beef cattle growth are predicted and the variance components are estimated considering the weight at standard ages as, for example, birth, weaning, yearling and final usingsingle-or multi-trait analyses (ALBUQUERQUE;EI FARO, 2008). 
Traits related to animal growth are adopted in beef cattle breeding programs as selection criteria, because the remuneration of breeders is based on the weight of carcasses (LAUREANO et al., 2011). Characteristics such as weight and weight gainsare economical and easy to be measured in a large number of individuals, and have genetic variability of intermediate magnitude in zebu cattle as Nellore and Tabapuã, promoting acceptable genetic gains (SOUSA JÚNIOR et al., 2010b).

The considerable increase in the production of beef cattle by genetic improvement has been achieved by selection, crossbreed and combination of both (BUENO et al., 2012). The genetic evaluation in multiracial populations combines the information of all animals belonging to the study population (pure and crossbred), and includes direct and maternal racial effects and the effects of heterosis in analyses (WILLIAMS et al., 2010). The accuracy of the predictions of the genetic merit of animals depends on reliable estimation of specific averages by racial composition, animal deviations from these averages, and genetic (co)variances between pure or crossbred relatives (CARDOSO;TEMPELMAN, 2004).

\section{RANDOM REGRESSION MODELS}

Random regression models (RRM) allow estimating coefficients of the covariance functions by the method of restricted maximum likelihood (REML). These models are suitable for longitudinal data analysis models, because they supply the deficiencies of conventional methods of quantitative genetic analysis, which consider phenotypic values (inherently continuous processes) as discrete processes. With RRM, the random regression coefficients as a function of time are obtained for each animal, instead of using the model of repeatability for singletrait or multiple traits model (MEYER, 1998).

In recent years, random regression models have been adopted as standard procedure for analysis longitudinal data in animal breeding. This methodology has been used in several domestic species such as beef cattle (ALBUQUERQUE and MEYER, 2001; DIAS et al., 2006) and dairy cattle (EL FARO and ALBUQUERQUE, 2003; ARAÚJO et al., 2006; SOUSA JÚNIOR et al., 2014). For longitudinal data study, such as growth traits, the use of RRM allows obtaining genetic parameters at any age within the range considered (SOUSA JÚNIOR et al., 2010b).

Another advantage of RRM is the possibility of estimating more accurately the genetic and phenotypic covariance components, because they take into account the measurements as a function of time, using information from all observations, and also allow obtaining estimates for the temporary environmental variances or error of measurement (KIRKPATRICK et al., 1990). 
Random regression coefficients can be fitted for each source of variation of the model. The covariance functions (CF) are considered an alternative for working with longitudinal data because they allow description of gradual change of the covariance in function of time and the prediction of variances and covariance for points along the growth curve (DIAS et al., 2006).

In Brazil, some studies using RRM have been conducted with the purpose of studying growth traits in beef cattle (DIAS et al., 2006; SOUSA JÚNIOR et al., 2012). Sakaguti et al. (2003) applied random regression models to estimate covariance functions for weights taken from 365 to 650 days of age in Tabapuã cattle, however, owing to computational limitations, linear and quadratic models were set uponly for animal effects, not considering the maternal effects. These authors concluded that RRM allowed estimating variance components at any age, and providing additional parameters useful for genetic evaluations Tabapuã'sbreed.

Random regression models are best suited for modelling weights, because they considered the continuous modification of the phenotype and of all fixed and random effects that compose it, as well as its parameters individual's age function (VALENTE et al., 2008). RRM do not require adjustments, which preserves the quality of information and prevents the elimination of data collected in distant ages of those set as default (ROBBINS et al., 2005). The best qualitative and quantitative use of information has a positive impact on the accuracy of evaluations (BERTRAND et al., 2006).

Albuquerque and Meyer (2001) estimated covariance functions using random regression models for records of weights from birth to 630 days of age in Nellore cattle, and these authors reported that random regressions can be decribed adequately forcovariance's changes according to the age. On the other hand, NOBRE et al. (2003) analyzed the growth curve of Nellore cattle from birth to 683 days of age using multiple trait models (MTM) and RRM, and observed that random regression models were more sensitive than MTM to sampling problems.

\section{LONGITUDINALDATA ANDGENETIC COVARIANCE}

The traits of interest for animal breeding that are measured several times during the life of the animal are considered as longitudinal data. Therefore, the simplest model for longitudinal data analysis is basically the model of repeatability, assuming that all the measurements taken over time represent the same trait. Characteristics such as monthly milk production and weight gain can be measured repeatedly throughout the animal's life, these being termed repeated traits over time or longitudinal traits (SOUSA JÚNIOR et al., 2010b).

According to Menezes (2010), the longitudinal traits can also be analyses by multiple trait models, assuming that each weight adjusted for standard ages is a different characteristic. Multi- 
trait genetic evaluations predict breeding values for different ages through the incorporation of genetic and residual covariance between the ages (SPIEDEL et al., 2010). Another important point in this type of analysis is that the number of parameters to be estimated increases sharply with increasing numbers of traits (MENEZES, 2010).

Random regression models have become standard in analyses of data arisen from animal production systems, especially in the last decade (HENDERSON JUNIOR, 1982; LAIRD and WARE, 1982). RRM assume that the genetic and permanent environment variances do not vary over time as the genetic and permanent environmental correlations between repeated measurements are equal to 1. According to Silva et al. (2008), it is possible that an animal A is genetically superior to an animal $\mathrm{B}$ at a given age, but not in other age, with respect to the evaluated characteristic.

In studies on animal breeding, it is observed that the application of RRM methodology is given mostly in the modelling of correlated residuals in studies of nonlinear growth curves (PALA et al., 2005). In the case of (co) variance components estimation, most studies limit the use of RRM only to the permanent environment effects of the animal (CARVALHEIRA et al., 1998; ALBUQUERQUE;MEYER, 2001). Therefore, it is observed a little number of studies in which the parameterization wasused for estimating genetic components, and in many of these studies the structured ante-dependence functions was used (JAFFRÉZIC and PLETCHER, 2000; JAFFREZIC et al., 2004).

A covariance function can be defined as a continuous function that provides the covariance of traits measured at different points of a trajectory, describing the covariance between measurements taken at certain ages as a function of these ages (VAN DER WERF; SCHAEFFER, 1997). Thus, when fitting a random regression model, it assumes a certain covariance structure between the random regression coefficients, which is imposed by fitted function, and can be characterized by a continuous function or a covariance function (PESSOA, 2011).

According to Meyer and Hill (1997), the covariance function coefficients can be estimated from random regression models. Thus, different functions can be used to adjust the trajectory over the time. Among the parametric functions, it highlights the Wilmink exponential function (WILMINK, 1987) and the logarithmic function of Ali and Schaeffer (ALI and SCHAEFFER, 1987).

Meyer (1998) reports that random regression models are a special case of covariance functions, and allow directly estimating the coefficients of the covariance functions by the restricted maximum likelihood method (REML). In an experiment for growth selection, Mercadante et al. (2002) used random regression model to estimate genetic parameters for days 
to calving in Nellore females, and reported that application of RRM to records of days tocalving provided detailed analysis of the behavior of genetic covariance and breeding value of the female reproductive performance over the course of its life, which may be appropriate in many studies.

\section{FINAL CONSIDERATIONS}

Brazil has the second largest cattle population primarily consisting of zebu animals in the world, becoming one of the most important production chains in the country. Thus, the beef cattle herds present great variability in production among and within the different regions of Brazil.

The reaction norms models (RNM) are being used to assess the effects of genotype environment interaction on different traits of economic importance. In the RNM, the expression of genotypes in different environments is described as a linear function of an environmental gradient, i.e. the reaction norms describe the phenotype that is expressed by a genotype as a function of the environment.

The beef cattle breeding programs aim to change the averages of the traits of economic interest and increase profit of production systems. However, the reaction norms allow to determining alternative waysof development and metabolism of a genotype in various possible environments.

\section{REFERÊNCIAS}

ALBUQUERQUE, L.G.; EL FARO, L. Comparações entre os valores genéticos para características de crescimento de bovinos da raça Nelore preditos com modelos de dimensão finita ou infinita. Revista Brasileira de Zootecnia. v.37, n.2, p.238-246, 2008.

ALBUQUERQUE, L.G.;MEYER,K. Estimates of covariance functions for growth from birth to 630 days of age in Nelore cattle. Journal of Animal Science. v. 79, n. 11, p. 2776-2789, 2001.

ALI, T. E.;SCHAEFFER, L. R. Accounting for covariances among test day milk yields in dairy cows. Canadian Journal of Animal Science. v. 67, p. 637-644, 1987.

AMARAL, R. S.et al. Tendências, parâmetros fenotípicos e genéticos de características de crescimento em bovinos Nelore mocho do Nordeste brasileiro. Revista Brasileira de Saúde Produção Animal. v.15, n.2, p.261-271 abr./jun., 2014.

AMBROSINI, D. P. Interação genótipos ambientes em bovinos da raça Nelore Mocha na Região Nordeste do Brasil obtido por normas de reação. Diego Pagung Ambrosini - Itapetinga - BA: UESB/Mestrado em Zootecnia, 2012.

ANCP - Associação Nacional de Criadores e Pesquisadores. Sumário do Programa de Melhoramento Genético da Raça Nelore - PMGRN/ Nelore Brasil. http://www.ancp.org.br. Acessado em 21/11/2009. 
ARAÚJO, C. V. et al. Uso de modelos de regressão aleatória para descrever a variação genética da produção de leite na raça Holandesa. Revista brasileira de Zootecnia. v. 35, n. 3, p. 975-981, 2006 (supl).

ASSOCIAÇÃO BRASILEIRA DAS INDÚSTRIAS EXPORTADORAS DE CARNE (ABIEC). Balanço da pecuária (2013). Disponível em: <http://www.abiec.com.br/img/Upl/perfil-290114800.jpg>. Acesso em: 06 de mar. 2014.

BERTRAND, J. K. et al. Implementation of random regression models for large scale evaluations for growth in beef cattle. In: WORLD CONGRESS ON GENETICS APLIED TO LIVESTOCK PRODUCTION, 8., 2006, Belo Horizonte. Proceedings... Belo Horizonte, 2006.

BIFFANI, S. et al. Fatores Ambientais e Genéticos sobre o Crescimento ao ano e ao Sobreano de Bovinos Nelore, criados no Nordeste do Brasil. Revista Brasileira de Zootecnia. v.28, n.3, p.468-473, 1999.

BUENO, R. S. et al. Métodos de estimação de efeitos genéticos não-aditivos para características de peso e perímetro escrotal em bovinos de corte mestiços. Revista Brasileira de Zootecnia. v. 41, n. 5, p. 1140-1145, 2012.

CARDOSO, F. F.; TEMPELMAN, R. J. Hierarchical Bayes multiplebreed inference with an application to genetic evaluation of a Nelore-Hereford population. Journal of Animal Science. v. 82, n. 6, p. 1589-1601, 2004.

CARVALHEIRA, J. G. V. et al. Application of an autoregressive process to estimate genetic parameters and breeding values for daily milk yield in a tropical herd of Lucena cattle and in United States Holtein herds. Journal of Dairy Science. v. 81, n. 10, p. 2738-2751. 1998.

CORRÊA, M. B. B. Caracterização da interação genótipo-ambiente no desempenho de bovinos Devon no Rio Grande do Sul via normas de reação obtidas por regressão aleatória. Pelotas, 2007. 87p. Tese (Programa de Pós-Graduação em Zootecnia, Área de Concentração, 2007.

DIAS, L. T. et al. Estimação de Estimação de parâmetros genéticos para peso do nascimento aos 550 dias de idade para animais da raça Tabapuã utilizando-se modelos de regressão aleatória.

Revista Brasileira de Zootecnia. v. 35, n. 5, p. 1915-1925, 2006.

EI FARO, L.; ALBUQUERQUE, L.G. Utilização de modelos de regressão aleatória para produção de leite no dia do controle, com diferentes estruturas de variâncias residuais. Revista Brasileira de Zootecnia. v. 32, n. 5.; p. 1104-1113, 2003.

FARIA, C.U. et al. Bayesian inference in a quantitative genetic study of growth traits in Nelore cattle (Bos indicus). Genetics and Molecular Biology. v.30, n.3, p.545-551. 2007.

GIANOLA, D.; FERNANDO, R. L. Bayesian methods in animal breeding theory. Journal of Animal Science. v. 63, p. 217-244.

HENDERSON Jr., C. R. Analysis of covariance in the mixed model: higher-level, nonhomogeneous, and random regressions. Biometrics. v. 38, p. 623-640, 1982.

JAFFRÉZIC, F.; PLETCHER, S. D. Statistical models or estimating the genetic basis of repeated measures and other function-valued traits. Genetics. v. 156, p. 913-922, 2000. 
JAFFRÉZIC, F.et al. Use of structures antedependence models for the genetic analysis of gro curves. Journal Animal Science. v. 82, p. 3465-3473. 2004.

KIRKPATRICK, M.; LOFSVOLD, D.; BULMER, M. Analysis of the inheritance, selection and evolution of growth trajectories. Genetics, v. 124, p. 979 - 993, 1990.

LAIRD, N. M., WARE, J. H. Random effects models for longitudinal data. Biometrics. v. 38, p. 963-974, 1982.

LAUREANO, M.M.M. et al. Estimativas de herdabilidade e tendências genéticas para características de crescimento e reprodutivas em bovinos da raça Nelore. Arquivo Brasileiro de Medicina Veterinária e Zootecnia. v.63, n.1, p.143-152, 2011.

MARTINEZ, L.M. et al. A biologia molecular como aliada no combate aos carrapatos. In: SIMPÓSIO DA SOCIEDADE BRASILEIRA DE MELHORAMENTO ANIMAL, 5., 2004, Pirassununga. Anais...Pirassununga: Sociedade Brasileira de Melhoramento Animal, 2004. p.1-3.

MENEZES, G. R. O. Uso de polinômios segmentados na modelagem de dados longitudinais de ponderal em bovinos da raça Tabapuã. Tese (Doutorado) - Universidade Federal de Viçosa, 2010.

MERCADANTE, M. E. Z. et al. Dias ao Parto de Fêmeas Nelore de um Experimento de Seleção para Crescimento. II - Modelo de Regressão Aleatória. Revista Brasileira de Zootecnia. Viçosa, v. 31, p. 1726-1733, 2002.

MEYER, K. Advances in methodology for random regression analyses. Australian Journal of Experimental Agriculture. v.45, p.847-858, 2005.

MEYER, K. Estimating covariance functions for longitudinal data using a random regression model. Genet. Sel. Evol., v. 30, p. 221-240, 1998.

MEYER, K.; HILL, W.G. Estimation of genetic and phenotypic covariance functions for longitudinal 'repeated' records by restrict maximum likelihood. Livestock Production Science, v.47, n.3, p.85-200, 1997.

MINISTÉRIO DA AGRICULTURA, PECUÁRIA E ABASTECIMENTO (MAPA). Projeções do agronegócio: mundial e brasileiro. Disponível em: 〈http://www.agricultura. gov.br> Acesso em: 20 mar 2009.

NOBRE, P. R. C. Analyses of growth curves of Nellore cattle by multiple-trait and random regression models. Journal of Animal Science. v. 81, n. 4, p. 918-926, 2003.

OLIVEIRA, M. R. A.Avaliação do crescimento de bovinos da raça tabapuã de estados nordestinos do Brasil utilizando Modelos de Regressão Aleatória. Piauí, 2015. Dissertação (Programa de Pós-Graduação em Zootecnia). Área de Concentração: Produção Animal, Mestre em Ciências) Universidade Federal do Piauí.

PALA, A.; SAVAS, T.; UGUR, F.; DAS, G. Growth curves of Turkish Saanem goats' grouped for weight and body mass index. Arch. Tierz. v. 48, n. 2, p. 185-193. 2005. 
PESSOA, M. C. Estudo do valor adaptativo anual de fêmeas da Raça Nelore utilizando Modelos de Regressão Aleatória. Dissertação-Universidade Estadual Paulista/Faculdade de Ciências Agrárias e Veterinárias, Jaboticabal 2011.

ROBBINS, K. R.; MISZTAL, I.; BERTRAND, J. K. A practical longitudinal model for evaluating growth in Gelbvieh cattle. Journal of Animal Science. v. 83, n.1, p. 29-33, 2005.

SILVA, F.F.; AQUINO, L.H.; OLIVEIRA, A.I.G. Estimativas de Parâmetros Genéticos de Curva de Crescimento de Gado Nelore (Bos indicus). Ciênc. agrotec., Lavras. Edição Especial, p.15621567, dez., 2002.

SILVA, M.A.; THIÉBAUT, J.T.L.; VALENTE, B.D.; et al. Modelos lineares aplicados ao melhoramento genético animal. FEPMVZ Editora. Escola de Veterinária da UFMG. 375p. 2008 .

SOUSA JÚNIOR, S.C. et al.Aplicação de modelos de regressão aleatória utilizando diferentes estruturas de dados. Ciência Rural. v. 44, n. 11, p. 2058-2063, 2014.

SOUSA JÚNIOR, S.C. et al. Estimativas de Herdabilidades e Correlações Genéticas para Características de Crescimento da Raça Tabapuã Utilizando Modelo de Regressão Aleatória. Revista Científica de Produção Animal, v. 12, n. 2, p.1 54-157, 2010a.

SOUSA JÚNIOR, S.C. et al. Genotype by environment interaction in different birth seasons for weight at 240, 365 and 450 days of age in Tabapuã cattle. Revista Brasileira de Zootecnia. v.41, n.10, p.2169-2175, 2012.

SOUSA JÚNIOR, S.C et al. Estimação de funções de covariância para características de crescimento da raça Tabapuã utilizando modelos de regressão aleatória. Revista Brasileira de Zootecnia. v.39, n.5, p.1037-1045, 2010 b.

VALENTE, B. D. et al. Estruturas de covariância de peso em função da idade de animais Nelore das regiões Sudeste e Centro-Oeste do Brasil. Arquivo Brasileiro de Medicina Veterinária e Zootecnia. v. 60, n. 2, p. 389-400, 2008.

VAN DER WERF, J.; SCHAEFFER, L.R. Random regression in animal breeding. Ontario: University of Guelph. p. 70, 1997.

WILLIAMS, J. L. et al. Estimation of breed and heterosis effects for growth and carcass traits in cattle using published crossbreeding studies. Journal of Animal Science. v. 88, p. 460-466, 2010 . 